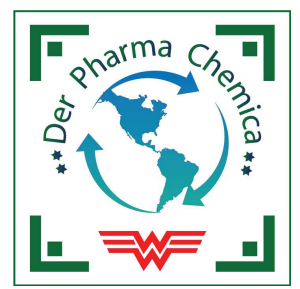

\author{
ISSN 0975-413X \\ CODEN (USA): PCHHAX
}

Der Pharma Chemica, 2016, 8(19):388-395

(http://derpharmachemica.com/archive.html)

\title{
Design and Modification of Copper Oxide Electrodes for Improving Conversion Coefficient Indoors Lights (PV-Cell) Photocells
}

\author{
Rahadian Zainul \\ Department of Physical Chemistry, Universitas Negeri Padang, Padang, Indonesia
}

\begin{abstract}
This research aims to investigate photocells reactor design can convert indoor lights energy into electrical energy. Indoor lights comes from sunlight entering into the room and fluorescent light irradiation. Design of photocells reactor use a panel of copper oxide $\left(\mathrm{Cu}_{2} \mathrm{O} / \mathrm{CuO}\right)$ of calcined $\mathrm{Cu}$ plate and filler electrolyte $\mathrm{Na}_{2} \mathrm{SO}_{4} 0.5 \mathrm{~N}$. Modification of electrode by n-p junction layer, which one of section $(n)$ and the others section ( $p)$. Photocells reactor was constructed by thickness of the glass pane, the distance between the electrodes, the interface layer, layer and coating reflector panels. In this research there are three design of photocells reactor, The first design is $R_{1}$, the thickness of the glass panel $3 \mathrm{~mm}$ thick reactor $15 \mathrm{~mm}$ without anti reflector. In this design, there are two type based on the difference at the junction of type $n,\left(R_{1 a}=\right.$ plate $C u ; R_{1 b}=$ plate Aluminum) generate 182.82 $m W / m^{2}$ and $21119644.3 \mathrm{NW} / \mathrm{m}^{2}$. Than, the second design of photocells reactor is $R_{2 a}$ (junction-type $n=$ plate Cu) and $R_{2 b}$ (junction-type $n=$ plate Al), a panel thickness of $15 \mathrm{~mm}$ and has a layer anti reflector provide power 214.95 $\mathrm{mW} / \mathrm{m}^{2}$ and $24163298.3 \mathrm{NW} / \mathrm{m}^{2}$. The last design of photocells reactor is $R_{3}\left(R_{3 a}=C u\right)$ and $R_{3 b}(\mathrm{Al})$, thickness of 9 $\mathrm{mm}$, the distance between the electrodes $0.30 \mathrm{~mm}$, using anti reflector carbon, giving each the power of 277.36 $\mathrm{mW} / \mathrm{m}^{2}$ and $31258420.91 \mathrm{NW} / \mathrm{m}^{2}$. The most optimum reactor design is $R_{3 b}$ with $2: 14 \%$ conversion capabilities (Intensity $=90.21$ foot candles) for indoor lights.
\end{abstract}

Keywords : Photocells, Reactor, Indoor Lights, Design, Copper Oxide

\section{INTRODUCTION}

Research in the field of photocatalyst widespread, especially in terms of applications. In environmental applications, has been widely applied to the photo-transformation of a compound of contaminants, such as humic acid photodegradation through semiconductor photocatalysts zinc oxide [ZnO] [1,2]. Another application is to obtain electrical energy by converting sun light on a photocell.

Conversion of renewable energy is still problematic, namely solar energy conversion efficiency is still low. Theoretically, the maximum efficiency of solar energy conversion is between $11 \%$ to $12 \%$ [110 $\mathrm{Wm}^{-2}$ to $120 \mathrm{Wm}^{-2}$ ] [3]. The first solar cell manufactured from crystalline silicon and has a conversion efficiency of $6 \%$. Developing research and improvement of solar cells continue to do, to be produced from the silicon crystal with a conversion efficiency of up to $25 \%$ [laboratory scale] and $22 \%$ [module marketed]. In the market there are several types of solar cell technologies available, including crystals, micro-crystalline and amorphous silicon. Due to higher efficiency and economies of scale, the world market is dominated by crystalline silicon solar cells, which reached $93.5 \%$ in 2005 [3]. 
The development of photovoltaic or PV research has lasted a long time. Since Hammond, AL publish, "Photovoltaic cells: direct conversion of solar energy", the study of photovoltaic cells developed with various aspects. [2] The first aspect of the reactor contents photovoltaic covering organic PV [4; 5], PV inorganic/polymer [6; 7] and Dyesensitized Solar Cell [8-10]. Dye-sensitized Solar Cell [DSSC] is made with the dye molecules, nanocrystalline metal oxides and organic electrolyte liquid [11]. Various polymers are used to increase the efficiency of PV cells [12]. Second, the design aspects of the surface panel PV cells, among other multilayer semiconductor surface [13], the surface of the patterned/nanocone [14], the surface of the nanowire [15; 16], and the film surface [13; 17]. Various efforts to improve the efficiency PV through surface modification, intended to make the light captured and absorbed by the surface of the PV, or retained longer on the surface of the photocatalyst [18].

Third, the development in the aspect of optics include absorber of light [19], strengthening and shifting light [20], the concentrator [21], anti-reflector [22], sensitizer [23], collector hole [24], the slope of the panel [25; 26 ] and block wall panels are integrated with semiconductor [27]. Fourth, in the aspect of the semiconductor PV cells, PV cell includes an N-type, P-type PV cells and heterojunction PV cells and PV cell multi P-N, have also been developed [28; 29]. This development was carried out to obtain a high energy conversion. Research reactors photocell light room already done Zainul et al [2015] to develop a copper electrode [32, 33].

On the other hand, the development of PV cells that work on a room's light intensity is lower than direct sunlight on an open area outside the room, is a challenge, especially in the development of a design that is able to increase the conversion reactor. On the one hand, the source of energy used low-power, and on the other hand required adequate PV cell design to work with the limitations of such energy in order to produce the best performance of the photocell.

\section{MATERIALS AND METHODS}

\section{TOOLS AND MATERIALS}

The tools used in this study are Multimeter (Heles), lightmeter, fluorescent light (Philip 10 watts), Scales Analytical Instruments glassware and computer correctly Sketchup 2015. The materials used in this study is glass (PT Asahimas), glass glue, $\mathrm{Cu}$ Plate, Al Plate, Sodium sulfate $\left(\mathrm{Na}_{2} \mathrm{SO}_{4}\right)$ (Merck), agar-agar powder, chloroform (Merck) and distilled water.

\section{Geometry Design of manufacturing PV cells (Photocells)}

The design of PV cells designed using computer software SketchUp adjustable geometry, 2015. Scale interior materials used in the room, such as the thickness of glass, and the type of glass used to manufacture PV cells. Prototype Reactor photocells made to resemble a wall panel, which is adapted to the interior panels in the room as in Figure 1

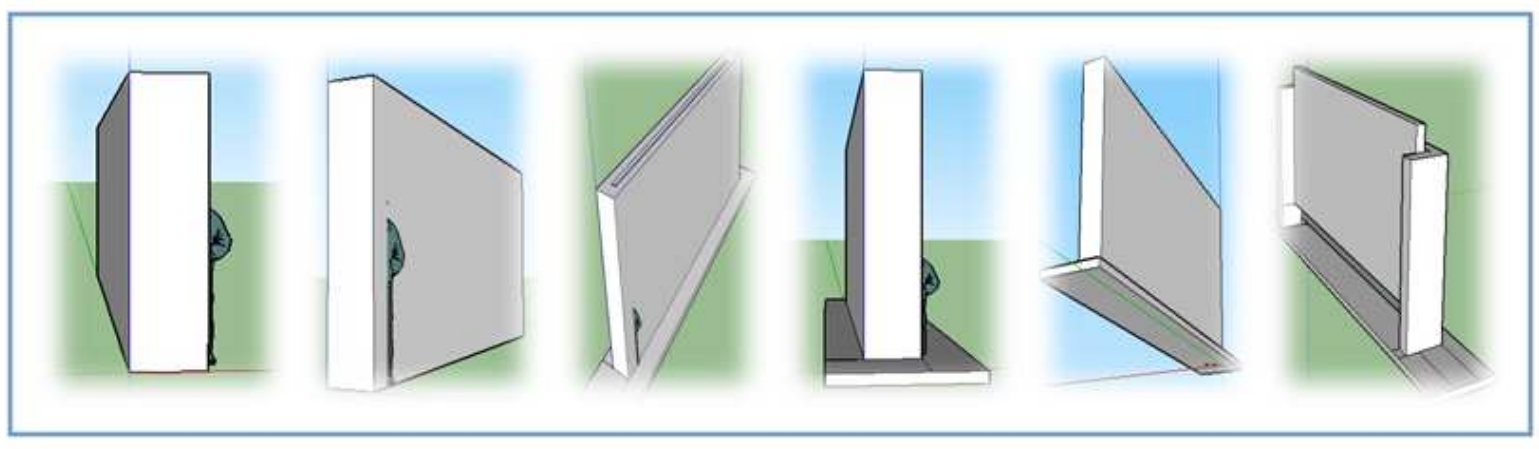

The design is done by designing three main reactor design and being 6 design after replacing n-p junctionnya. PV cells are designed with a variety of distances and the type of electrode used. Design or the design of PV cells made using a model Design $1\left(R_{1 a}\right)$, Design $1 b\left(R_{1 b}\right)$, design $2 a\left(R_{2 a}\right)$, the design $2 b\left(R_{2 a}\right)$, design 3a $\left(R_{3 a}\right)$ and Design 3 $\left(R_{3 b}\right)$. All design was designed and made by using glass and silicon glue. All PV cell is tested efficiency and performance, in order to obtain optimum PV cells for further testing. Cathode $\left(\mathrm{Cu}_{2} \mathrm{O}-\mathrm{CuO}\right)$ and anode $(\mathrm{Cu}, \mathrm{Al})$ bounded by the glass ( $3 \mathrm{~mm}$ thick) and within $6 \mathrm{~mm}$, to design 1a, 1b, 2a and 2b. On the design 1a and 1b, the outer glass wall of the anodes used black glass, while the design $2 \mathrm{a}$ and $2 \mathrm{~b}$ used carbon paper. On the design $3 \mathrm{a}$ and $3 \mathrm{~b}$, 
cathode and anode are only limited by paper membrane thickness of $0.32 \mathrm{~mm}$ and the outer glass anode lined with carbon paper.

Preparation of copper oxide electrode

Copper oxide electrode is made by burning $\mathrm{Cu}$ plate at temperature variations of $300,350,400,450$ and $500^{\circ} \mathrm{C}$, for 1 hour.

\section{Preparation of $\mathrm{Na}_{2} \mathrm{SO}_{4}$ electrolyte solution in form jelly}

A total of 3.6 grams of $\mathrm{Na}_{2} \mathrm{SO}_{4}$ dissolved in $100 \mathrm{~mL}$ of water and added agar-agar powder as much as 0.5 grams. The mixture was stirred and heated to boiling until the solution becomes clear. After that, add several drops of chloroform. In hot conditions the electrolyte solution is poured into PV cells.

\section{Measurement of voltage and current of photocells}

Each PV cell is filled with a gelatinous sodium sulfate, and then irradiated with sunlight coming into the room and fluorescent light bulbs. Current and voltage of each cell was measured by using a multimeter.

\section{RESULTS AND DISCUSSION}

\section{Design and manufacture of $P V$ cells}

PV cells (photocells) Design $1\left(R_{1 a}\right)$, which is a clear transparent glass with a thickness of $3 \mathrm{~mm}$, cut to a size of 2 $\mathrm{cm}$ x $12 \mathrm{~cm}$ by 4 units. Size $10 \mathrm{~cm}$ x $12 \mathrm{~cm} 2$ pieces, and a size of $10 \mathrm{~cm} \mathrm{x} 14 \mathrm{~cm} 1$ piece and $4 \mathrm{~cm} \mathrm{x} 14 \mathrm{~cm} 1$ piece. In the electrode $\mathrm{Cu}_{2} \mathrm{O} / \mathrm{CuO}$ is part of the entry/exposed to light the room, and the other part is closed carbon paper (Cu electrode) as in Figure 2.

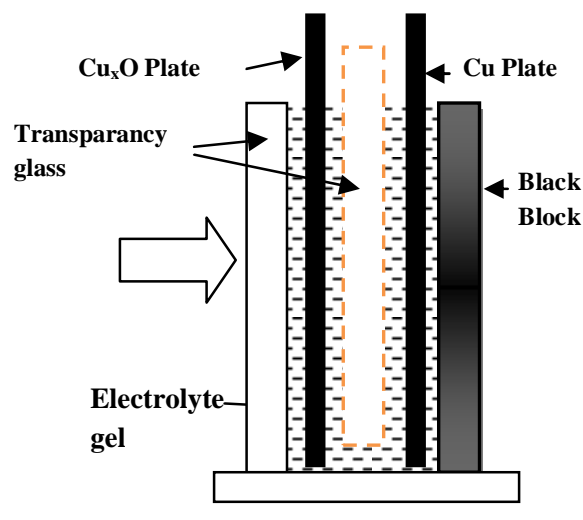

(a)

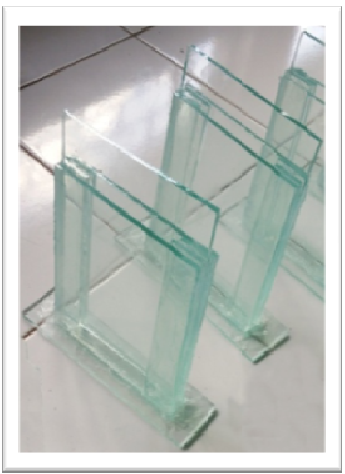

(b)

Figure 2. Schematic and Design PV cells $1\left(R_{1 a}\right)$ (a) Schematic PV cells and (b) of PV cells that have been made

PV Cells Design $2\left(R_{1 b}\right)$, which is a clear transparent glass with a thickness of $3 \mathrm{~mm}$, cut to a size of $2 \mathrm{~cm} \times 12 \mathrm{~cm}$ by 4 units. Size $10 \mathrm{~cm} \times 12 \mathrm{~cm} 2$ pieces, and a size of $10 \mathrm{~cm} \times 14 \mathrm{~cm} 1$ piece and $4 \mathrm{~cm} \times 14 \mathrm{~cm} 1$ piece. In the electrode $\mathrm{Cu}_{2} \mathrm{O} / \mathrm{CuO}$ is part of the entry/exposed to light the room, and the other part is closed carbon paper ( $\mathrm{Al}$ electrode) as in figure 3 . 


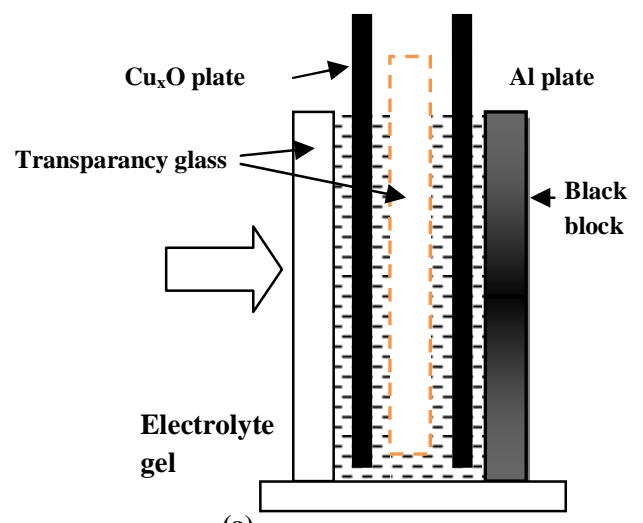

(a)

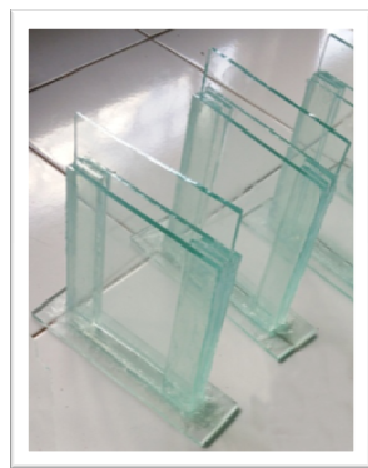

(b)

Figure 3. Schematic and Cells PV Design 2 (R1b) (a) Schematic design of PV cells and (b) of PV cells that have been made

PV Cells Design $2\left(\mathrm{R}_{2 \mathrm{a}}\right)$, which is transparent clear glass and black glass with a thickness of $3 \mathrm{~mm}$, cut to a size of 2 $\mathrm{cm} \times 12 \mathrm{~cm}$ by 4 units. Size $10 \mathrm{~cm}$ x $12 \mathrm{~cm} 2$ pieces (one clear and one black), and a size of $10 \mathrm{~cm} \times 14 \mathrm{~cm} 1$ piece and $4 \mathrm{~cm} \times 14 \mathrm{~cm} 1$ piece. On the electrode $\mathrm{Cu}_{2} \mathrm{O} / \mathrm{CuO}$ is clear glass, and the $\mathrm{Cu}$ electrode parts are black glass like Figure 4.

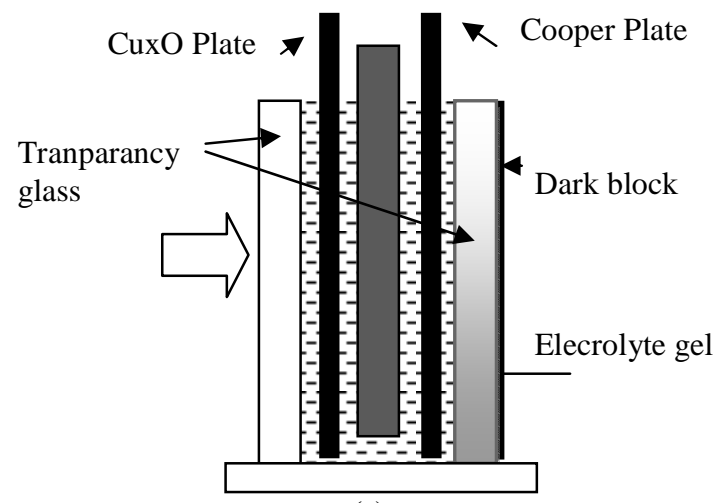

(a)

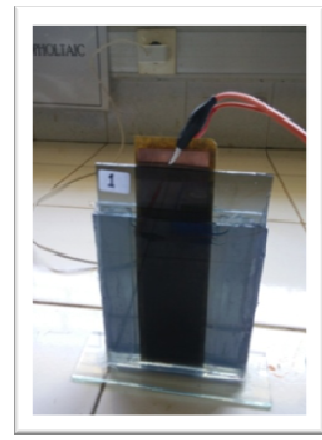

Figure 4. Schematic Design and PV Cell $2\left(R_{2 a}\right)(a)$ Schematic design of PV cells and (b) of PV cells that have been made

PV Cells Design $2\left(\mathrm{R}_{2 \mathrm{~b}}\right)$, which is transparent clear glass and black glass with a thickness of $3 \mathrm{~mm}$, cut to a size of 2 $\mathrm{cm} \times 12 \mathrm{~cm}$ by 4 units. Size $10 \mathrm{~cm}$ x $12 \mathrm{~cm} 2$ pieces (one clear and one black), and a size of $10 \mathrm{~cm} \times 14 \mathrm{~cm} 1$ piece and $4 \mathrm{~cm} \times 14 \mathrm{~cm} 1$ piece. On the electrode $\mathrm{Cu}_{2} \mathrm{O} / \mathrm{CuO}$ is clear glass, and $\mathrm{Al}$ electrode parts are black glass like Figure 5.

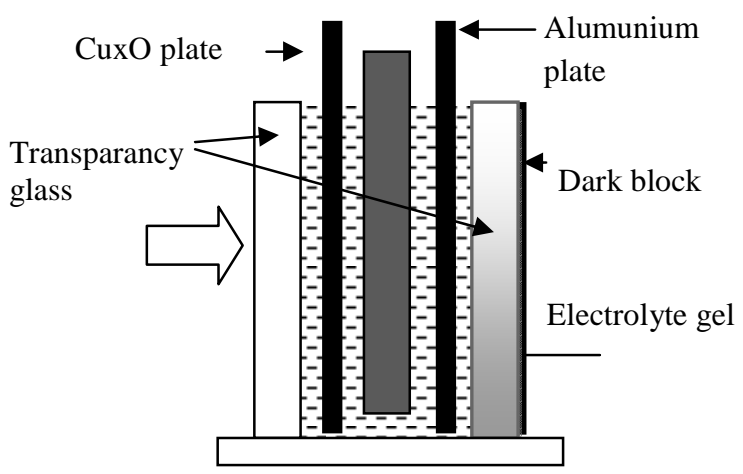

(a)

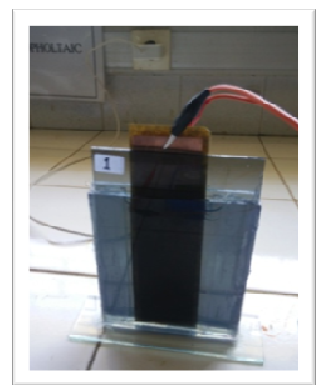

(b)

Figure 5. Schematic Design and PV Cell $2\left(R_{2 b}\right)$ (a) Schematic design of PV cells and (b) of PV cells that have been made 
PV Cells Design $3\left(\mathrm{R}_{3 \mathrm{a}}\right)$, which is a clear transparent glass with a thickness of $3 \mathrm{~mm}$, cut to a size of $2 \mathrm{~cm} \times 12 \mathrm{~cm} 2$ pieces. Size $10 \mathrm{~cm}$ x $12 \mathrm{~cm} 2$ pieces, and $4 \mathrm{~cm}$ x $14 \mathrm{~cm} 1$ piece. On the transparent electrode $\mathrm{Cu}_{2} \mathrm{O} / \mathrm{CuO}$, part dark, the $\mathrm{Cu}$ electrode. Between electrodes $\mathrm{Cu}_{2} \mathrm{O}-\mathrm{CuO} / \mathrm{Cu}$ is limited only by the insulating paper such as drawing 6 .

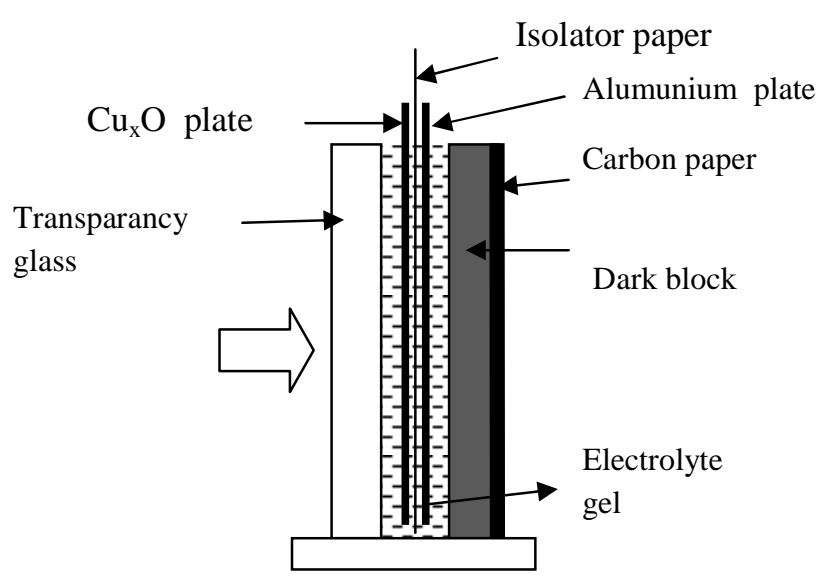

(a)

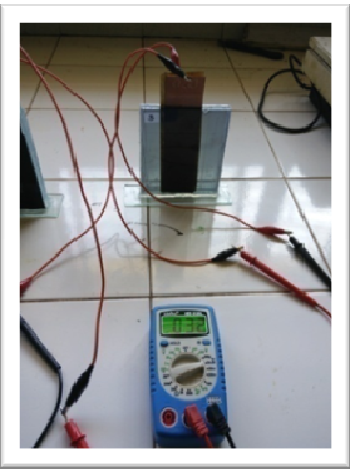

(b)

Figure 6. Scheme and PV Cell Design $3\left(R_{3 a}\right)$ (a) Schematic design of PV cells and (b) of PV cells that have been made

PV Cells Design $3\left(R_{3 b}\right)$, which is a clear transparent glass with a thickness of $3 \mathrm{~mm}$, cut to a size of $2 \mathrm{~cm} \times 12 \mathrm{~cm} 2$ pieces. Size $10 \mathrm{~cm}$ x $12 \mathrm{~cm} 2$ pieces, and $4 \mathrm{~cm}$ x $14 \mathrm{~cm} 1$ piece. On the transparent electrode $\mathrm{Cu}_{2} \mathrm{O} / \mathrm{CuO}$, part dark, the $\mathrm{Cu}$ electrode. Between electrodes $\mathrm{Cu}_{2} \mathrm{O}-\mathrm{CuO} / \mathrm{Al}$ is limited to peanut rice paper like Figure 7.
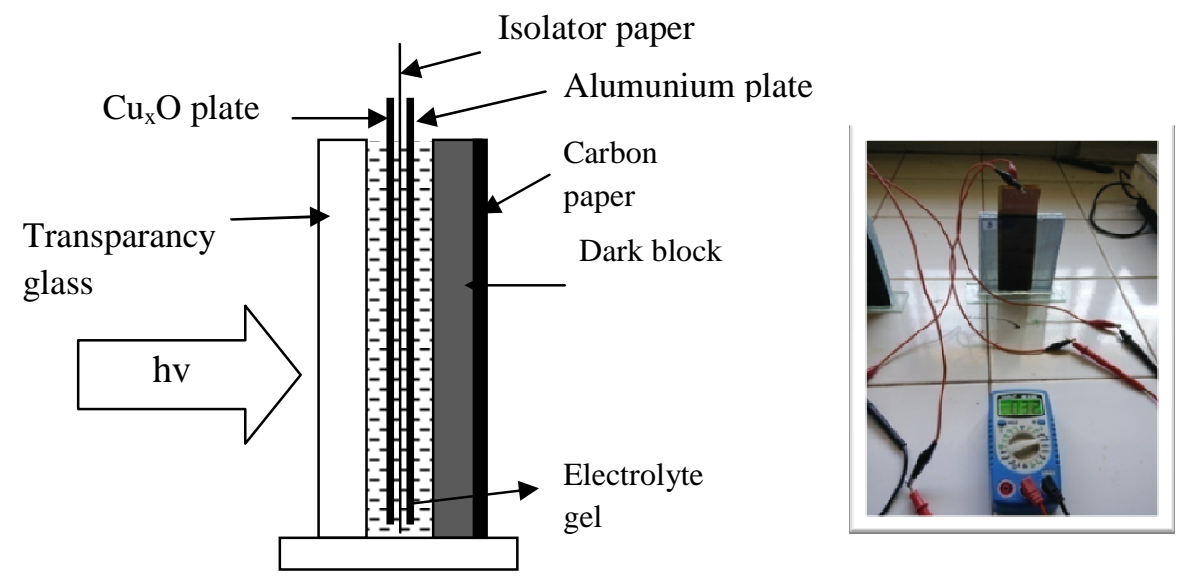

(a)

(b)

Figure 7. Schematic and PV Cell Design $3\left(R_{3 b}\right)$ (a) Schematic design of PV cells and (b) of PV cells that have been made

\section{Results Measurement Capabilities PV Cells}

From the results of current and voltage measurements from the source of light coming into the room, in the formation of several PV cells electrode pair $\mathrm{Cu}_{2} \mathrm{O}-\mathrm{CuO} / \mathrm{Cu}$ (to $\mathrm{R}_{1 \mathrm{a}}, \mathrm{R}_{2 \mathrm{a}}$ and $\mathrm{R}_{3 \mathrm{a}}$ ) and PV cell electrode pair $\mathrm{Cu}_{2} \mathrm{O}-$ $\mathrm{CuO} / \mathrm{Al}$ (for $\mathrm{R}_{1 \mathrm{~b}}, \mathrm{R}_{2 \mathrm{~b}}$ and $\mathrm{R}_{3 \mathrm{~b}}$ ) flows generated each $\mathrm{R}_{1 \mathrm{a}}, \mathrm{R}_{1 \mathrm{~b}}, \mathrm{R}_{2 \mathrm{a}}, \mathrm{R}_{2 \mathrm{~b}}, \mathrm{R}_{3 \mathrm{a}}$ and $\mathrm{R}_{3 \mathrm{~b}}$ amounted to 22.6; 165; 25.5; 183; 28.2 and $200 \mathrm{uA}$. Meanwhile, the measurement of the voltage generated sequentially each of $R_{1 \mathrm{a}}, \mathrm{R}_{1 \mathrm{~b}}, \mathrm{R}_{2 \mathrm{a}}, \mathrm{R}_{2 \mathrm{~b}}, \mathrm{R}_{3 \mathrm{a}}$ and $\mathrm{R}_{3 \mathrm{~b}}$ is $30.02 ; 475 ; 31.15 ; 490 ; 36.5$; and $580 \mathrm{mV}$ as shown in Figure 12. 


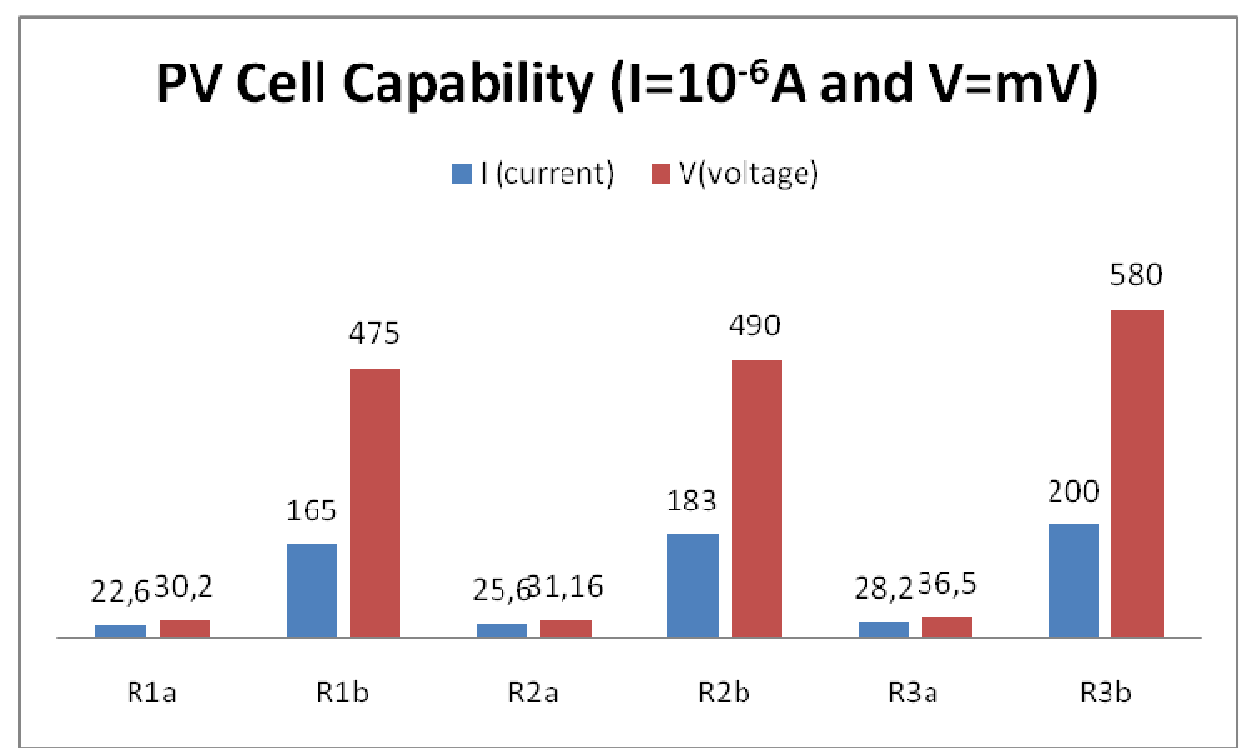

Figure 8. The ability of PV cells based on Geometric Design of photocells

From the results of current and voltage measurements from the source of light that comes into the room, the generated power PV cells each $\mathrm{R}_{1 \mathrm{a}}, \mathrm{R}_{1 \mathrm{~b}}, \mathrm{R}_{2 \mathrm{a}}, \mathrm{R}_{2 \mathrm{~b}}, \mathrm{R}_{3 \mathrm{a}}$ and $\mathrm{R}_{3 \mathrm{~b}}$ amounted to 182821.9; 21119644.3; 214954.5; 24163298.3 ; 277364.6; and $31258420.9 \mathrm{NW} / \mathrm{m}^{2}$ as shown in Figure 8.

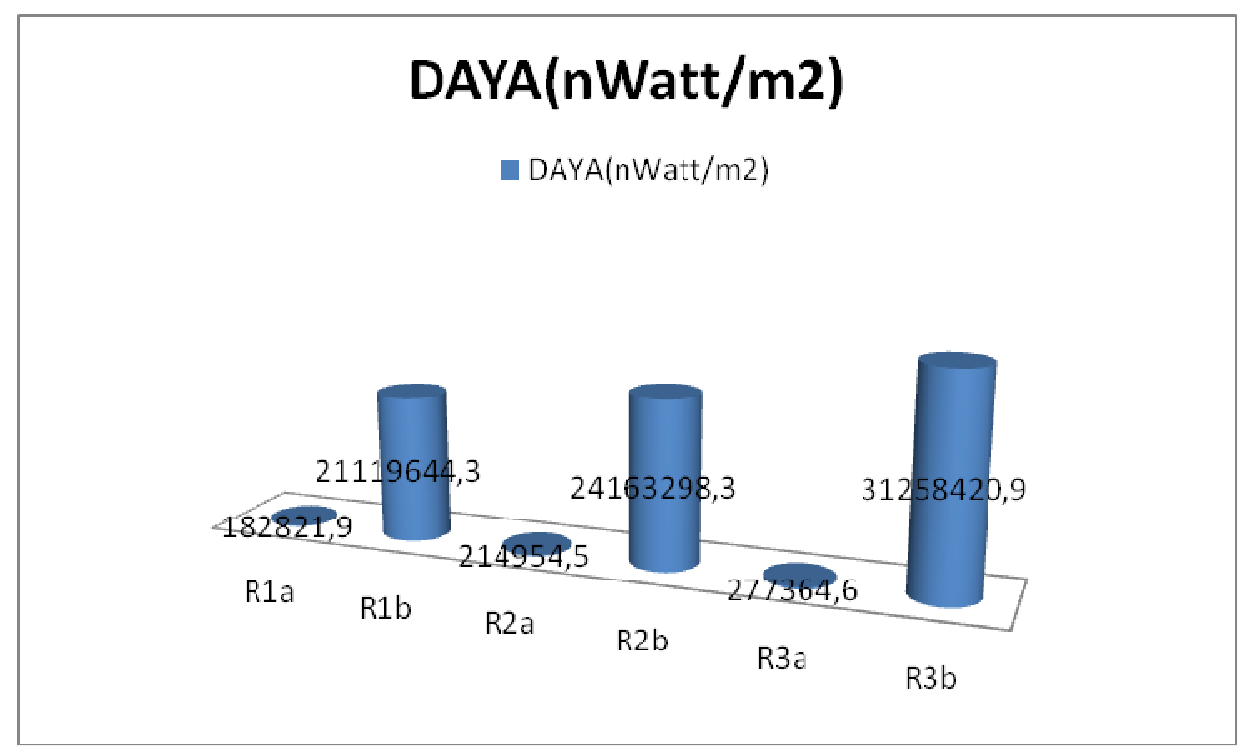

Figure 9. Power Reactor produced PV cells for each design

In R1A, PV cells' ability lowest among all existing designs. This is due to the design R1A, the distance between the cathode and the anode is greater than $R_{3 a}$ and $R_{3 b}$. In $R_{1 a}, R_{1 b}, R_{2 a}$ and $R_{2 b}$, the distance between the cathode and the anode reaches $6 \mathrm{~mm}$. Distance of the two electrodes is assumed, the total sum of the thick barrier reactor made of glass $(3 \mathrm{~mm})$ and the cathode plate placement $\left(\mathrm{Cu}_{2} \mathrm{O}-\mathrm{CuO}\right)$ of $1.5 \mathrm{~mm}$ and a plate anodes $(\mathrm{Cu}$ or $\mathrm{Al})$ also amounted to $1.5 \mathrm{~mm}$. The greater the distance between the plate reactors This further reduces the ability of PV cells generate electric current and voltage (29). 
The increased power of PV cell designs based on the distance compared to the effect of the metal at the anode replacement is very high. This is reflected in a significant increase in the ability of PV cells compared $R_{1 b} / R_{1 a}$ by 114.5 times when the anode is replaced on the copper plate with aluminum plate. It is also common in the design $R_{2 a}$ and $R_{2 b}$ to reach 111.4-fold increase, and at $R_{3 a} / R_{3 b}$ reached 111.7 fold. The significant increase is due to factors that are aluminum junction $\mathrm{N}$ type, so rich in electrons. This leads to a tendency to provide electron voltage difference increases the ability of PV cells in generating electricity.

On the use of anti-reflector using dark glass and carbon paper, its effect on the ability of PV cells is not significant. This is evidenced by the change in current and voltage in the $\mathrm{R}_{1 \mathrm{a}}$ and $\mathrm{R}_{2 \mathrm{a}}$ with increased 0.17-fold (approximately $17 \%)$. In $\mathrm{R}_{2 \mathrm{a}} / \mathrm{R}_{1 \mathrm{a}}$ with anti-reflector (silencer) two blocks $\left(\mathrm{R}_{2 \mathrm{a}}\right)$ than one block $\left(\mathrm{R}_{1 \mathrm{a}}\right)$, an increase of about $17 \%$. This is because light is absorbed in a dark colored blocks will increase the ability of PV cells on Cathode and Anode of the stabilizing influence of photons (31).

At the time of the distance between the cathode and the anode is reduced $(0: 27 \mathrm{~mm})$, the increased capabilities of PV cells increased by $29 \%\left(\mathrm{R}_{2 \mathrm{a}} / \mathrm{R}_{1 \mathrm{a}}\right)$ and $151 \%\left(\mathrm{R}_{3 \mathrm{a}} / \mathrm{R}_{1 \mathrm{a}}\right)$. This is because the smaller the distance between the cathode and anode, a potential barrier is formed will be greater and occur rapidly by the influence of photons. It also makes it easier for electrons to flow from the cathode to the anode and onwards towards a circuit that generates an electromotive force (32).

\section{Reactor efficiency of photocells}

The ability to convert PV cells produced by calculating the percentage of power from the PV cell light on the panel compared with those produced PV cells or power is converted. In this study used space light intensity is determined by the intensity of the unit foot candles and flux. Based on the measurements by using light sensors acquired results or figures in units fc (foot candles) and flux. Conversion is done by multiplying the multiplier factor that is 10.76 for every $1 \mathrm{fc}$ thus obtained unit lumens. Unit lumens converted to $\mathrm{W} / \mathrm{m}^{2}$ by multiplying by 0.0015 multiplicative factors.

Lightmeter of measurements, light intensity obtained in the study room of $90.21 \mathrm{fc}$. So, if converted would be as follows:

$$
\begin{aligned}
\mathrm{I} & =90.21 \times 10.76 \text { lumens } \\
& =970.6596 \text { lux } \times \text { lumens } \\
& =970.6596 \times 0.0015 \mathrm{~W} / \mathrm{m}^{2} \\
& =1.46 \mathrm{~W} / \mathrm{m}^{2}
\end{aligned}
$$

While the determination of efficiency can be determined by comparing the intensity of light space with the power to convert PV cells.

$\varphi=\mathrm{I} /$ Io $\times 100 \%$

The efficiency of the six reactors photocells of the calculations, respectively as shown in Table 1.

Table 1. The conversion efficiency at various photocells Reactor Design

\begin{tabular}{|c|c|c|c|}
\hline REACTOR & POWER $\left(\mathbf{n W} / \mathbf{m}^{\mathbf{2}}\right)$ & POWER $\left(\mathbf{W} / \mathbf{m}^{\mathbf{2}}\right)$ & $\square \square \square \square \square$ \\
\hline $\mathrm{R}_{1 \mathrm{a}}$ & 182821.9 & 0.000182822 & 0.0125 \\
\hline $\mathrm{R}_{1 \mathrm{~b}}$ & 21119644.3 & 0.021119644 & 1.4466 \\
\hline $\mathrm{R}_{2 \mathrm{a}}$ & 214954.5 & 0.000214955 & 0.0147 \\
\hline $\mathrm{R}_{2 \mathrm{~b}}$ & 24163298.3 & 0.024163298 & 1.655 \\
\hline $\mathrm{R}_{3 \mathrm{a}}$ & 277364.6 & 0.000277365 & 0.019 \\
\hline $\mathrm{R}_{3 \mathrm{~b}}$ & 31258420.9 & 0.031258421 & 2.141 \\
\hline
\end{tabular}

Based on the design of the reactor cell $R_{3 b}$ seen that the design provides the greatest power compared $R_{1 a} / R_{3 a}$. This is due to various factors, including the distance between the electrodes, the electrodes are used so that the selection of the potential barrier generated even greater, and the effect of catching and trapping of light incident on the glass panel PV cells (33). 


\section{CONCLUSION}

From the results of a design to variable distances, then obtained the smaller the distance of the two electrodes, the greater power of the PV cell. $R_{3 a}$ and $R_{3 b}$ power greater than PV cell power reactor design No. $1\left(R_{1 a}\right), 2\left(R_{1 b}\right), 3$ $\left(R_{2 a}\right)$ and $4\left(R_{2 b}\right)$. In Design $R_{3 a}$ and $R_{3 b}$ is obtained distance between Cathode and Anode of 12:27 mm. Influence damper (anti-reflector) light can increase the ability of the reactor by $17 \%$ without changing the distance between the electrodes, but if the electrode spacing is reduced by 21.2 times the increased ability of PV cells by $151 \%$.

To improve the ability of PV cells significantly, modifications can be made by replacing the anode plate opposite character to the cathode plate, so that the resulting voltage greater barrier. From these results $\mathrm{R}_{3 \mathrm{a}}$ Design provides the greatest power $31258420.9 \mathrm{NW} / \mathrm{m}^{2}$ or 170 -fold compared $\mathrm{R}_{1 \mathrm{a}}$ and provide an efficiency of $2: 14 \%$.

\section{REFERENCES}

[1] Zainul, R. 2016. Der Pharmacia Lettre 8(15):120-124

[2] Zainul, R. 2016. Der Pharmacia Lettre 8(15):176-179

[3] Parlevliet D, Moheimani NR. 2014. Aquatic biosystems 10:4

[4] Hammond AL. 1972. Science 178:732-3

[5] Feron K, Belcher WJ, Fell CJ, Dastoor PC. 2012. International journal of molecular sciences 13:17019-47

[6] Chen YC, Hsu CY, Lin RY, Ho KC, Lin JT. 2013. ChemSusChem 6:20-35

[7] Alturaif HA, ZA AL, Shapter JG, Wabaidur SM. 2014. Molecules 19:17329-44

[8] Kim H, Ok S, Chae H, Choe Y. 2012. Nanoscale research letters 7:56

[9] Kao MC, Chen HZ, Young SL, Lin CC, Kung CY. 2012. Nanoscale research letters 7:260

[10] Lee CH, Rhee SW, Choi HW. 2012. Nanoscale research letters 7:48

[11] Stergiopoulos T, Rozi E, Karagianni CS, Falaras P. 2011. Nanoscale research letters 6:307

[12] Kim YK, Kang HJ, Jang YW, Lee SB, Lee SM, et al. 2008. International journal of molecular sciences 9:274556

[13] Liu M, Rieger R, Li C, Menges H, Kastler M, et al. 2010. ChemSusChem 3:106-11

[14] Krishnan A, Das S, Krishna SR, Khan MZ. 2014. Optics express 22 Suppl 3:A800-11

[15] Thiyagu S, Pei Z, Jhong MS. 2012. Nanoscale research letters 7:172

[16] Liu K, Qu S, Zhang X, Tan F, Wang Z. 2013. Nanoscale research letters 8:88

[17] Lundgren C, Lopez R, Redwing J, Melde K. 2013. Optics express 21 Suppl 3:A392-400

[18] Kaltenbrunner M, White MS, Glowacki ED, Sekitani T, Someya T, et al. 2012. Nature communications 3:770

[19] Gundel P, Schubert MC, Heinz FD, Woehl R, Benick J, et al. 2011. Nanoscale research letters 6:197

[20] Song L, Uddin A. 2012. Optics express 20 Suppl 5:A606-21

[21] Sablon K, Sergeev A, Vagidov N, Antipov A, Little J, Mitin V. 2011. Nanoscale research letters 6:584

[22] Stefancich M, Zayan A, Chiesa M, Rampino S, Roncati D, et al. 2012. Optics express 20:9004-18

[23] Perl EE, McMahon WE, Bowers JE, Friedman DJ. 2014. Optics express 22 Suppl 5:A1243-56

[24] Li Y, Wei L, Chen X, Zhang R, Sui X, et al. 2013. Nanoscale research letters 8:67

[25] Jia Y, Li X, Li P, Wang K, Cao A, et al. 2012. Nanoscale research letters 7:137

[26] Guo X, Li H, Ahn BY, Duoss EB, Hsia KJ, et al. 2009. Proceedings of the National Academy of Sciences of the United States of America 106:20149-54

[27] Alexandru C. 2013. TheScientificWorldJournal 2013:205396

[28] Kim JH, Lee KJ, Roh JH, Song SW, Park JH, et al. 2012. Nanoscale research letters 7:11

[29] Dou L, You J, Hong Z, Xu Z, Li G, et al. 2013. Advanced materials 25:6642-71

[30] ur Rehman A, Lee SH. 2013. TheScientificWorldJournal 2013:470347

[31] Sears WM, Fortin E. 1984. Solar Energy Materials 10 93-103

[32] R.Trethewey. K. 1988. longman Group, UK Limited:pages. 83, 349-61

[33]Zainul; R, Alif; A, Aziz; H, Arief; S, Syukri;, Yasthopi A. 2015. Journal of Chemical and Pharmaceutical Research 7, 9s:246-56

[34]Zainul R, Alif A, Aziz H, Arief S, Syukri, Munaf E. 2015. Research Journal of Pharmaceutical Biological Chemical Science 6.4. July-August:353-61

[35]Ping-Kuan Chang, Ting-Wei Kuo, Mau-Phon Houng, Chun-Hsiung Lu, Yeh C-H. 2012 IEEE journal 978-14577-18235.

[36]Zainul; R, Alif; A, Aziz; H, Arief; S, Syukri;, Yasthopi A. 2015. Jurnal Riset Kimia, Universitas Andalas. 